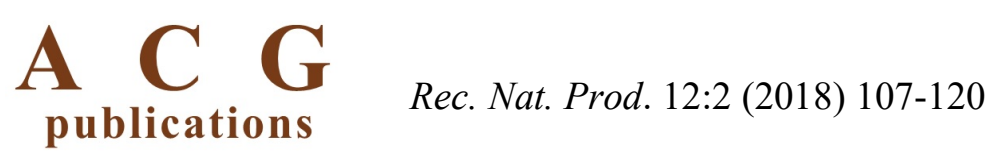

records of natural products

\title{
An Overview on the Role of Macular Xanthophylls in Ocular Diseases
}

\author{
Sezen Yilmaz Sarialtin ${ }^{* \oplus}$ and Tulay Coban ${ }^{\odot}$
}

\author{
Ankara University, Faculty of Pharmacy, Department of Pharmaceutical Toxicology, 06100 \\ Tandoğan, Ankara, Türkiye
}

(Received April 24, 2017; Revised June 28, 2017; Accepted July 10, 2017)

\begin{abstract}
Macula lutea, is the center of the retina of the eye, contains high concentrations of lutein and zeaxanthin which can act as a filter against short-wavelength (blue) light. Lutein and zeaxanthin are the only carotenoids detected in human lens which exhibit highly strong free radical scavenging activity. Many epidemiological studies, clinical trials, animal experiments have suggested that lutein and zeaxanthin have antiinflammatory potential with their high antioxidant properties. Several eye diseases including, age-related macular degeneration, uveitis and retinitis pigmentosa are caused by ocular inflammation. Some studies have shown that lutein and zeaxanthin could be protective, curative and preventive against ocular inflammation induced diseases and other ocular disorders such as cataract, glaucoma and choroideremia. The mechanisms responsible for these effects are absorption of near-ultraviolet and blue light, reduction of oxidative stress, inflammation and angiogenesis. Lutein and zeaxanthin can be taken from dietary supplements or a diet high in fruits, vegetables such as kale, spinach and turnip greens. The aim of this review is to evaluate the relationship between the consumption of lutein and zeaxanthin and eye diseases.
\end{abstract}

Keywords: Eye diseases; lutein; macular xanthophylls; ocular diseases; zeaxanthin. (C) 2018 ACG Publications. All rights reserved

\section{Introduction}

Carotenoids are naturally-occurring plant pigments and important constituents of a healthy diet with their established contribution to the antioxidant defense system in whole body especially in macula [1-3]. Carotenoids, which absorb a wavelength range of 350-550 nanometers (nm), are nonpolar organic pigments. Carotenoids divided into two major groups; orange pigments which are called carotenes and yellow pigments which are called xanthophylls [4]. The group of xanthophylls includes lutein, zeaxanthin, neoxanthin, violaxanthin, capsanthin, canthaxanthin, astaxanthin, echionine, flavoxanthin, alpha $(\alpha)$ - and beta $(\beta)$-cryptoxanthin [5]. It is widely though that carotenoids

\footnotetext{
${ }^{*}$ Corresponding author: E- Mail: Sezen.Yilmaz@ankara.edu.tr

The article was published by ACG Publications 
can be protective against the formation and development of eye diseases due to their antioxidant properties [6-9].

Lutein and its stereo-isomer zeaxanthin are two carotenoids that belong to the xanthophylls subclass as shown in Figure 1. Lutein and zeaxanthin are the most dense compounds which are found at the center of the fovea that is the yellowish pigmented area called macula lutea. Due to the fact that it is referred to as macular pigment [10-15]. Macular pigment is located at the center of the retina and the site of highest visual acuity. Macula of the retina is yellow due to rich lutein and zeaxanthin content. Although the

function of macular pigment remains unclear, there are various possibilities. One of the claim is that lutein and zeaxanthin protect retina against oxidative stress from the damage of blue-light by inhibiting lipid peroxidation and c-fos gene expression [16,17]. The other is about antioxidant properties of lutein and zeaxanthin that are highly potent quenchers of singlet oxygens and other free radicals [18-20]. The near-ultraviolet and blue light filtering properties of macular pigment could be a result of free radical scavenging capacity and protective characteristics against the harmful effects of short wavelength light to the retina [21-26].

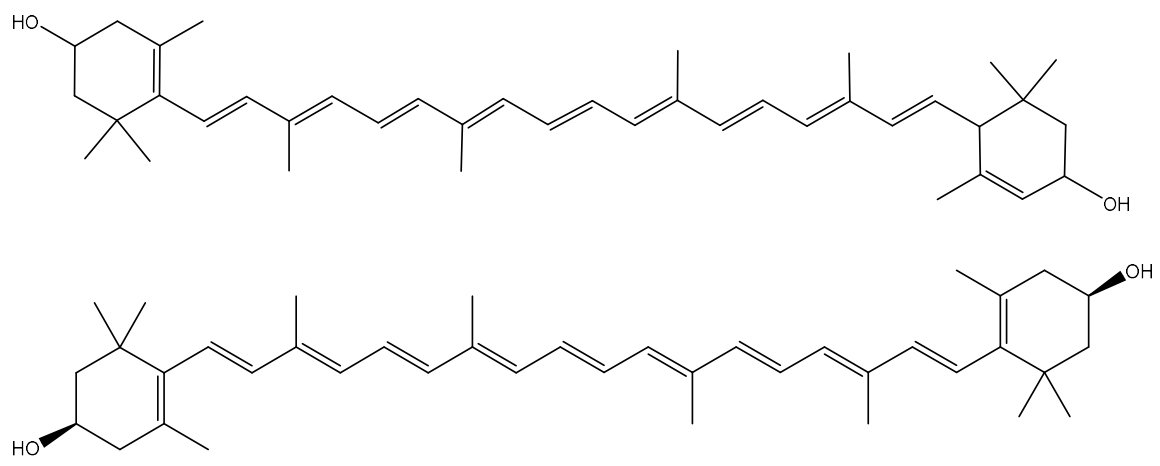

Figure 1. The molecular structure of lutein (above) and zeaxanthin (below).

U.S. National Library of Medicine National Center for Biotechnology Information (2017).

(The chemical structures of the compounds were drawn by using ChemDraw Professional Ver.16.0.1.44)

Recent epidemiological studies have suggested that lutein and zeaxanthin play roles in the reduction of the risk for inflammation-related eye disease, specifically age-related macular degeneration (AMD), uveitis, retinitis pigmentosa, scleritis and also cataracts, glaucoma, retinal ischemia, choroideremia, etc [27-33]. Low systemic and retinal levels of lutein and zeaxanthin are adversely associated with the risk of AMD and other eye related disease [34-37]. The mechanisms responsible for the effects of lutein and zeaxanthin include prevention of phototoxic damage by absorption of blue light, reduction of oxidative stress through free radical scavenging, antioxidant, anti-angiogenic, anti-inflammatory properties as shown in Figure 2 [38- 43]. 


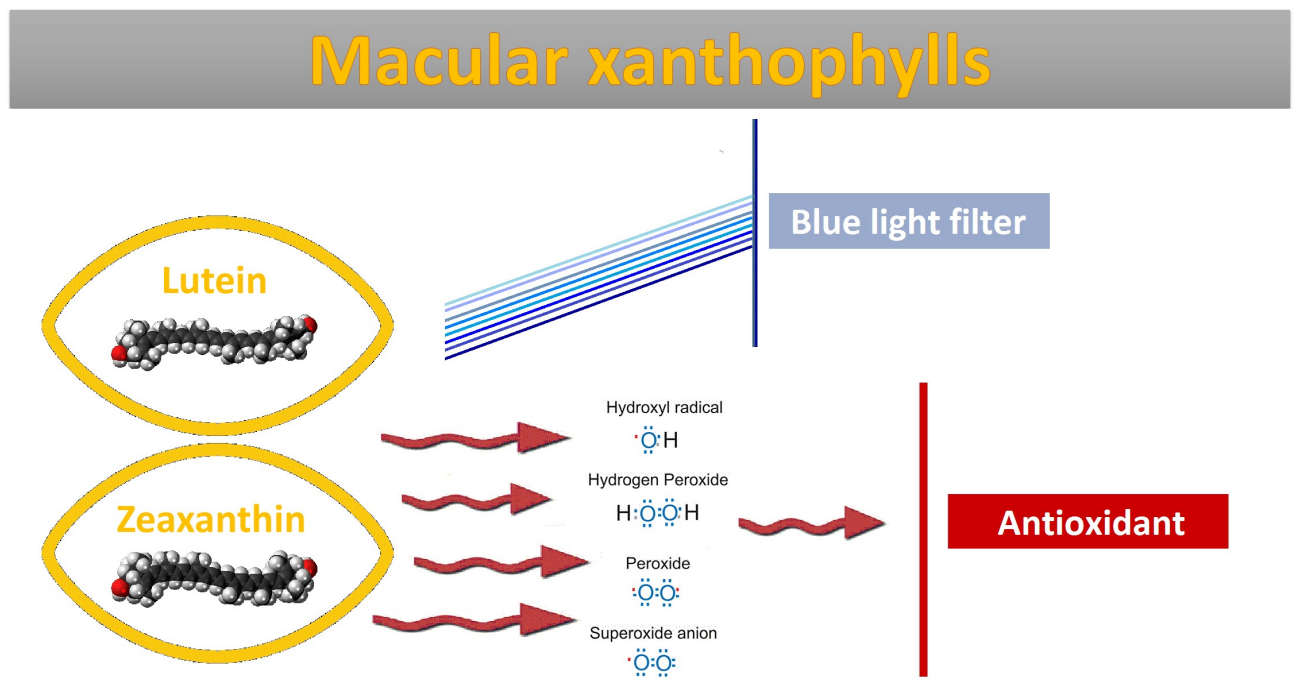

Figure 2. An overview for potential action mechanism of macular pigments (original).

Table 1. Common foods rich in lutein and zeaxanthin.

\begin{tabular}{|c|c|c|c|}
\hline $\begin{array}{l}\text { Lutein } \\
(\mathrm{mg}) \text { per }\end{array}$ & $\begin{array}{l}+\quad \text { zeaxanthi } \\
\text { r } 100 \mathrm{~g} \text { food }\end{array}$ & Food & $\begin{array}{l}\text { utein + zeaxanthin } \\
\text { (mg) per } 100 \mathrm{~g} \text { food }\end{array}$ \\
\hline Arugula, raw & 3.55 & Lettuce, cos or romaine, raw & 2.31 \\
\hline Balsam-pear, leafy tips, cooked, boiled, drained & 2.63 & $\begin{array}{l}\text { Mustard greens, cooked, boiled, } \\
\text { drained }\end{array}$ & 10.4 \\
\hline Basil, fresh & 5.65 & Nuts, pistachio nuts, raw & 2.9 \\
\hline Beans, fava, in pod, raw & 1.81 & $\begin{array}{l}\text { Onions, spring or scallions (includes } \\
\text { tops and bulb), raw }\end{array}$ & 1.13 \\
\hline Beet greens, cooked, boiled, drained, with salt & 1.81 & Parsley, fresh & 5.56 \\
\hline Broccoli raab, cooked & 1.68 & Peas, green, cooked, boiled, drained & 2.59 \\
\hline Brussels sprouts, raw & 1.59 & Peppers, sweet, red, freeze-dried & 5.79 \\
\hline Carrot, dehydrated & 1.05 & Pumpkin, raw & 1.5 \\
\hline Chard, swiss, raw & 11 & Radicchio, raw & 8.83 \\
\hline Chicory greens, raw & 10.3 & $\begin{array}{l}\text { Rose Hips, wild (Northern Plains } \\
\text { Indians) }\end{array}$ & 2 \\
\hline Chrysanthemum, garland, raw & 3.83 & Spices, coriander leaf, dried & 2.42 \\
\hline $\begin{array}{l}\text { Collards, frozen, chopped, cooked, boiled, } \\
\text { drained }\end{array}$ & 10.89 & Spices, paprika & 18.94 \\
\hline Corn bran, crude & 1.35 & Spices, pepper, red or cayenne & 13,15 \\
\hline Cornmeal, degermed, enriched, yellow & 1.62 & $\begin{array}{l}\text { Spinach, frozen, chopped or leaf, } \\
\text { cooked, boiled, drained }\end{array}$ & 15.69 \\
\hline Cowpeas, young pods with seeds, raw & 0.93 & Squash, summer, all varieties, raw & 2.12 \\
\hline Cress, garden, raw & 12.5 & Squash, summer, scallop, raw & 2.31 \\
\hline Dandelion greens, raw & 13.61 & $\begin{array}{l}\text { Stinging Nettles, blanched (Northern } \\
\text { Plains Indians) }\end{array}$ & 4.17 \\
\hline Drumstick leaves, cooked, boiled, drained & 1.74 & Sweet potato leaves, raw & 14.72 \\
\hline Egg, yolk, dried & 1.13 & Taro leaves, raw & 1.93 \\
\hline Grape leaves, raw & 1.74 & Tomatoes, sun-dried & 1.42 \\
\hline Kale, frozen, cooked, boiled, drained, with salt & 19.69 & Turnip greens, raw & 12.82 \\
\hline $\begin{array}{l}\text { Lambsquarters, steamed (Northern Plains } \\
\text { Indians) }\end{array}$ & 6.16 & Watercress, raw & 5.76 \\
\hline Leeks, (bulb and lower leaf-portion), raw & 1.9 & & \\
\hline
\end{tabular}

Lutein and zeaxanthin cannot be synthesized in mammals and must be obtained from the diet for distribution to various tissues, particularly the retina [10,11,12]. Lutein and zeaxanthin are found in 
egg products, fruits and vegetables, especially green leafy plants, including, kale, spinach, turnip greens and collards highly as shown in Table 1 [11-15].

The recommended daily intake for lutein and zeaxanthin is 6 to $20 \mathrm{mg}$ for adults to reduce the risk of ocular diseases [34,35]. Lutein and zeaxanthin are accumulated in lipophilic tissues such as adipose and liver tissue $[44,45]$. Lutein and zeaxanthin are absorbed with fat, which transport via high density lipoproteins (HDLs) mostly and low density lipoproteins (LDLs) lower [36,37]. Lutein and zeaxanthin, which are also called macular xanthophylls, show their effects by filtering high energy visible light, mostly with a peak of absorption at $446 \mathrm{~nm}$ and ultraviolet radiation lesser, inhibiting lipid peroxidation and reducing reactive species such as singlet oxygen and hydroxyl radical [46-48]. These carotenoids have several benefits on human health, including neuroprotective effects [49-51], anti-carcinogenic effects [52-55], anti-diabetic effects [56-58], cardioprotective effects [59- 61], protective effects on skin damages and ocular diseases [62-65]. Particularly, several studies showed the role of lutein and zeaxanthin in eye diseases. The studies we have chosen about this issue are listed in Table 2.

\section{Role of Lutein and Zeaxanthin in Ocular Diseases}

\subsection{Role of Lutein and Zeaxanthin in Cataract}

Occurrence of the cataractogenesis depends on some factors, including oxidative stress $[66,67,68]$. Consuming antioxidants by daily diet or as supplements may reduce this stress. Some studies indicate that there is a strong relationship between cataract development and lutein consumption [69-72].

Karppi et. al reported a study on the correlation between plasma lutein and zeaxanthin levels and the risk of age-related nuclear cataract. Samples were taken from Finnish men and women who had different lifestyles (education, body mass index (BMI), HDL-LDL levels), habits (smoking, alcohol consumption) and disease (hypertension, diabetes). The results of this study have shown that the risk of nuclear cataract in older people, with an average age of 70 years, decreased with high plasma lutein and zeaxanthin levels [69]. Another study was conducted on a Mediterranean population over the age of 60, suffering from several types of cataract such as nuclear, cortical, PSC, mixed and also cataract surgery. According to the results of this study, high plasma zeaxanthin levels were associated with lower risk of nuclear cataract significantly, whereas no relation with the other types of cataracts. Furthermore, high plasma lutein concentrations and total lutein levels were not related to any type of cataract markedly [70]. Aqueous humor samples were collected from 40 men and women with senile cataract development in both eyes during cataract surgery. These subjects had taken supplements containing lutein. After and before taking these supplements, some antioxidant enzyme levels, including superoxide dismutase (SOD), L-ascorbic acid, reduced GSH, superoxide scavenging capacity, the levels of hydrogen peroxide $\left(\mathrm{H}_{2} \mathrm{O}_{2}\right)$ and total amount of hydroperoxides $(\mathrm{TH}$, including $\mathrm{H}_{2} \mathrm{O}_{2}$ and the peroxides of lipids, peptides, proteins, nucleic acids and nucleotides) were measured in the aqueous humor and changes were determined. Superoxide scavenging capacity increased by taking lutein containing supplements in both men and women subjects. However, lutein intake caused an increase in the levels of $\mathrm{H}_{2} \mathrm{O}_{2}$ and a decrease in the levels of TH in postmenopausal females, whereas there were no huge differences in these levels in males. Although it is uncertain, it is thought that estrogen is the cause of the differences in these levels between the genders [71]. Vianna et al. conducted a study about using a dye containing trypan blue combined with lutein and zeaxanthin during cataract surgery. This combination was used during cataract surgery by phacoemulsification for screening anterior capsulorhexis in patients. The result of this study indicated that this combined dye might be an alternative for continuous circular capsulorhexis (CCC) in human due to its safe, effective and antioxidant profile [72]. The results of Chew et al.'s study was contrary to the most studies. More than 4000 people at the age of 73.1 meanly divided four treatment groups; placebo, lutein/zeaxanthin, DHA/EPA, lutein/zeaxanthin+DHA/EPA. In contrast to the other studies, this placebo-controlled, randomized study indicated that lutein and zeaxanthin supplementation had no significant beneficial or adverse effects on cataract surgery, any type of cataract and losing sight [73]. 
Table 2. Effects of lutein and zeaxanthin treatment on different eye diseases (original).

\begin{tabular}{|c|c|c|c|c|c|}
\hline Reference & Study group & Participants & Health status & Treatment & Results \\
\hline Karppi J. et al., 2012 & Human & $\begin{array}{l}\text { Group 1: } 559 \text { female } \\
\text { Group 2: } 1130 \text { male }\end{array}$ & $\begin{array}{l}\text { nuclear, cortical, } \\
\text { posterior subcapsular } \\
\text { cataracts (PSC), } \\
\text { mixed and cataract } \\
\text { surgery }\end{array}$ & lutein/zeaxanthin & $\begin{array}{l}\text { Zeaxanthin treatment decreased the risk of nuclear cataract. } \\
\text { No relation with the other types of cataract. }\end{array}$ \\
\hline Hayashi R. et al., 2014 & Human & $\begin{array}{l}\text { Group 1: } 18 \text { male } \\
\text { Group 2: } 22 \text { female }\end{array}$ & senile cataract & Ocuvite + Lutein $\AA$ & Lutein-based treatment was effective in reducing oxidative stress. \\
\hline $\begin{array}{l}\text { Vianna L.M. et al., } \\
2014\end{array}$ & Human & $\begin{array}{l}\text { Group 1:25 ( } 25 \text { eyes of } 25 \text { patients performed by } 25 \text { different } \\
\text { surgeons) } \\
\text { Group 1:lutein/zeaxanthin treated, } 10 \mathrm{mg} / 2 \mathrm{mg}(\mathrm{n}=787)\end{array}$ & cataract surgery & lutein and zeaxanthin & $\begin{array}{l}\text { A lutein-based dye (s) could be an alternative dye for anterior capsulorhexis } \\
\text { during cataract surgery. }\end{array}$ \\
\hline AREDS-2, 2013 & Human & $\begin{array}{l}\text { Group 2:docosahexaenoic acid (DHA)/eicosapentaenoic acid (EPA) } \\
3 \text { treated, } 350 \mathrm{mg} / 650 \mathrm{mg}(\mathrm{n}=803) \\
\text { Group 3:lutein/zeaxanthin+DHA and EPA ( } \mathrm{n}=794) \\
\text { Group 4:placebo (n=775) }\end{array}$ & AMD & lutein and zeaxanthin & $\begin{array}{l}\text { No beneficial or adverse effects was shown on subjects with cataract surgery, } \\
\text { any type of cataract and losing sight. }\end{array}$ \\
\hline $\begin{array}{l}\text { Huang Y.M. et al., } \\
2015\end{array}$ & Human & $\begin{array}{l}\text { Group 1:lutein treated } 10 \mathrm{mg}(\mathrm{n}=26) \\
\text { Group 2:lutein treated } 20 \mathrm{mg}(\mathrm{n}=27) \\
\text { Group 3:lutein }(10 \mathrm{mg})+\text { +eaxanthin }(10 \mathrm{mg})(\mathrm{n}=27) \\
\text { Group 4:placebo }(\mathrm{n}=28)\end{array}$ & early AMD & lutein and zeaxanthin & $\begin{array}{l}\text { Lutein treatment caused increasing in macular pigment optical density } \\
\text { (MPOD) and N1-P1. }\end{array}$ \\
\hline Made S.M et al., 2014 & Human & $\begin{array}{l}\text { Group 1:patients treated lutein-enriched egg yolk }(\mathrm{n}=52) \\
\text { Group 2:control }(\mathrm{n}=49)\end{array}$ & AMD & lutein-enriched egg yolk & $\begin{array}{l}\text { Plasma lutein concentrations in treated group were increased. } \\
\text { The increases in serum total and LDL cholesterol levels were not significant. }\end{array}$ \\
\hline Huang F.F. et al., 2014 & Human & $\begin{array}{l}\text { Group 1:patients with early AMD }(\mathrm{n}=51) \\
\text { Group 2:patients medium AMD }(\mathrm{n}=51) \\
\text { Group 3:control (wo AMD) }(\mathrm{n}=51)\end{array}$ & early-late AMD & lutein and zeaxanthin & $\begin{array}{l}\text { Serum HDL levels were related with AMD development. } \\
\text { No change in other levels. }\end{array}$ \\
\hline AREDS-2, 2014 & Human & $\begin{array}{l}\text { Group 1:lutein/zeaxanthin treated, } 10 \mathrm{mg} / 2 \mathrm{mg}(\mathrm{n}=1044) \\
\text { Group 2:DHA and EPA 3, treated, } 1.0 \mathrm{~g}(\mathrm{n}=1068) \\
\text { Group 3:lutein/zeaxanthin+DHA and EPA }(\mathrm{n}=1079) \\
\text { Group 4:placebo }(\mathrm{n}=1012)\end{array}$ & late AMD & lutein/zeaxanthin & $\begin{array}{l}\text { Positive correlation was shown between lutein/zeaxanthin supplementation and } \\
\text { progression of late AMD. }\end{array}$ \\
\hline He R.R. et al., 2011 & Male BALB/C mice & $\begin{array}{l}\text { Group 1:lutein treated, } 12.5 \mathrm{mg} / \mathrm{ml}(\mathrm{n}=18) \\
\text { Group 2:lutein treated, } 25 \mathrm{mg} / \mathrm{ml}(\mathrm{n}=18) \\
\text { Group 3:control }(\mathrm{n}=18) \\
\text { Group 4:model }(\mathrm{n}=18)\end{array}$ & uveitis & lutein & Glutathione (GSH) and vitamin $\mathrm{C}$ levels were increased after lutein treatment. \\
\hline Sasaki M. et al., 2009 & C57BL/6 mice & $\begin{array}{l}\text { Group 1:lutein treated }(\mathrm{n}=9) \\
\text { Group 2:lutein treated with endotoxin-induced uveitis (EIU) }(\mathrm{n}=13) \\
\text { Group 3:control }(\mathrm{n}=9)\end{array}$ & uveitis & lutein & $\begin{array}{l}\text { Lutein supplementation caused improving in visual damages, rhodopsin levels } \\
\text { and glial fibrillary acidic protein (GFAP) expressions. }\end{array}$ \\
\hline Igras E. et al., 2013 & Human & $\begin{array}{l}\text { Group 1:patients with open angle glaucoma }(\mathrm{n}=40) \\
\text { Group 2:normal controls w/o ocular disease }(\mathrm{n}=54)\end{array}$ & $\begin{array}{l}\text { glaucoma (open } \\
\text { angle) }\end{array}$ & $\begin{array}{l}\text { lutein, zeaxanthin and } \\
\text { mesozeaxanthin }\end{array}$ & $\begin{array}{l}\text { MPOD levels were lower in patients with open angle glaucoma } \\
\text { than control. }\end{array}$ \\
\hline $\begin{array}{l}\text { Giaconi J.A. et al., } \\
2012\end{array}$ & human & $\begin{array}{l}\text { Group 1:women with glaucoma }(\mathrm{n}=77) \\
\text { Group 2:women wo glaucoma }(\mathrm{n}=507)\end{array}$ & glaucoma & $\begin{array}{l}\text { healthy diet contains lutein, } \\
\text { zeaxanthin, vitamin A, C, E }\end{array}$ & $\begin{array}{l}\text { Diet-enriched vitamin and carotenoids decreased the risk of } \\
\text { glaucoma. }\end{array}$ \\
\hline
\end{tabular}




\begin{tabular}{|c|c|c|c|c|c|}
\hline Hu B.J. et al., 2011 & human & $\begin{array}{l}\text { Group 1:patient supplied with lutein and zeaxanthin }(\mathrm{n}=30) \\
\text { Group 2:patients w/o lutein and zeaxanthin supplementation }(\mathrm{n}=30) \\
\text { Group 3:control }(\mathrm{n}=30)\end{array}$ & diabetic retinopathy & lutein and zeaxanthin & Lutein and zeaxanthin concentrations in treated group were lower than control. \\
\hline Lima V.C. et al., 2010 & human & $\begin{array}{l}\text { Group 1:control (nondiabetics) }(\mathrm{n}=14) \\
\text { Group 2:type } 2 \text { diabetes wo retinopathy }(\mathrm{n}=17) \\
\text { Group 3:type } 2 \text { diabetes with retinopathy }(\mathrm{n}=12) \\
\text { Group 1:control ( } \mathrm{n}=9 \text { ) }\end{array}$ & diabetic retinopathy & lutein and zeaxanthin & $\begin{array}{l}\text { Lutein and zeaxanthin treatment caused increasing MPOD levels more in } \\
\text { nondiabetic patients than diabetics. }\end{array}$ \\
\hline Dilsiz N. et al., 2006 & $\begin{array}{c}\text { Male } \\
\text { Long-Evans rats }\end{array}$ & $\begin{array}{l}\text { Group 2:I/R }(\mathrm{n}=9) \\
\text { Group 3:tocopherol-treated }(\mathrm{I} / \mathrm{R}+\text { gamma tocopherol) }(\mathrm{n}=9) \\
\text { Group 4:lutein-treated }(\mathrm{I} / \mathrm{R}+\text { +lutein) }(\mathrm{n}=8) \\
\text { Group 5:Trigonella-treated }(\mathrm{I} / \mathrm{R}+\text { Trigonella) }(\mathrm{n}=8) \\
\text { Group 6:Teucrium-treated }(\mathrm{I} / \mathrm{R}+\text { Teucrium })(\mathrm{n}=8)\end{array}$ & retinal ischemia & lutein & $\begin{array}{l}\text { Lutein treatment improved malondialdehyde (MDA) levels and increased } \\
\text { GSH. }\end{array}$ \\
\hline Li S.Y. et al., 2012 & $\begin{array}{c}\text { Male } \\
\text { C57BL/6N mice }\end{array}$ & $\begin{array}{l}\text { Group 1:lutein treated }(\mathrm{n}=8) \\
\text { Group 2:sham control }(\mathrm{n}=8) \\
\text { Group 3:vehicle treated }(\mathrm{n}=8)\end{array}$ & retinal ischemia & lutein & $\begin{array}{l}\text { The levels of nuclear factor kappa B (NF-Kb), interleukin (IL)-1 } 1 \beta \text { and } \\
\text { cyclooxygenase (COX-2) reduced, no differences in tumor necrosis factor- } \alpha \\
\text { (TNF- } \alpha \text { ) and cell viability in lutein treated group. }\end{array}$ \\
\hline Woo T.T. et al., 2013 & $\begin{array}{c}\text { Male } \\
\text { Sprague-Dawley rats }\end{array}$ & $\begin{array}{l}\text { Group 1:lutein treated }(\mathrm{n}=40) \\
\text { Group 2:vehicle treated }(\mathrm{n}=39)\end{array}$ & retinal detachment & lutein & $\begin{array}{l}\text { Lutein treatment improved caspase- } 3 \text { and caspase- } 8 \text { expression. } \\
\text { No difference was found in caspase- } 9 \text {. }\end{array}$ \\
\hline Li S.Y. et al., 2009 & $\begin{array}{c}\text { Male } \\
\text { C57BL/6N mice }\end{array}$ & $\begin{array}{l}\text { Group 1:lutein treated }(\mathrm{n}=7) \\
\text { Group 2:vehicle treated }(\mathrm{n}=11)\end{array}$ & retinal ischemia & lutein & $\begin{array}{l}\text { Lutein treatment improved in the levels of nitrotyrosine (NT) } \\
\text { and poly-ADP-ribose (PAR). }\end{array}$ \\
\hline Zhao D.Y. et al., 2003 & human & $\begin{array}{l}\text { Group 1:patients with retinitis pigmentosa (RP), choroideremia } \\
\text { (CHM) and Stargardt macular dystrophy ( } \mathrm{n}=30 \text { ) } \\
\text { Group 2:control }(\mathrm{n}=76 \text { ) }\end{array}$ & $\begin{array}{l}\text { RP, CHM } \\
\text { Stargardt macular } \\
\text { dystrophy }\end{array}$ & lutein and zeaxanthin & $\begin{array}{l}\text { No differences was found in the levels of lutein and zeaxanthin in patients with } \\
\text { RP and CHM, while lower levels in patients with Stargardt macular dystrophy. }\end{array}$ \\
\hline Duncan J.L. et al., 2002 & human & $\begin{array}{l}\text { Group 1:patients with CHM }(\mathrm{n}=13) \\
\text { Group 2:normal vision }(\mathrm{n}=40)\end{array}$ & $\mathrm{CHM}$ & lutein & No differences was found in progression of $\mathrm{CHM}$ \\
\hline
\end{tabular}




\subsection{Role of Lutein and Zeaxanthin in AMD}

A meta-analysis focused to determine the impacts of lutein and zeaxanthin supplementation on 1176 patients suffering from AMD. Lutein and zeaxanthin supplementation caused visual performance improvement in the patients with AMD compared to the placebo group [74]. Another meta analysis conducted by Wang et al. to evaluate the effects of lutein and zeaxanthin supplement on the conditions such as MPOD and visual acuity (VA). Three different groups: lutein-zeaxanthin, luteinDHA and lutein-vitamin/mineral combinations were examined. MPOD and VA improved significantly in lutein treated group against placebo. Differences in the levels of MPOD were more severe than VA [75]. The effects of lutein and zeaxanthin on subjects with early AMD were investigated. Different concentrations of lutein and zeaxanthin $(10 \mathrm{mg}$ lutein, $20 \mathrm{mg}$ lutein, $10 \mathrm{mg}$ lutein $+10 \mathrm{mg}$ zeaxanthin or placebo) were supplied to 112 patients for 2 years to enhance macular pigment levels and functional retinal changes. MPOD and N1-P1 response densities increased in lutein treated AMD groups. Also, retinal sensitivity was enhanced in the central retina meanly [76]. Eggs are extremely nutritious food that contain many vitamins, minerals, carotenoids including lutein and zeaxanthin. Patients over the age of 50 who had early symptoms of AMD consumpted lutein-enriched egg yolk based buttermilk drink daily for a year. Plasma lutein concentrations in the treated group increased significantly while the increases in serum LDL and total cholesterol (TC) levels were not compared to the control [77]. Daily intake of lutein and zeaxanthin were calculated by asking questions about food consumption to the subjects with early/late AMD and without AMD. Also, serum concentrations of lutein, zeaxanthin and serum lipids, including serum TC, triglyceride (TG), HDL and LDL were measured and compared. Not all serum lipids, but serum HDL levels were associated with AMD development [78]. The Age-Related Eye Disease Study (AREDS) was conducted to evaluate the therapeutic effects of vitamin $\mathrm{C}$, vitamin $\mathrm{E}$, zinc with copper and $\beta$-carotene on AMD. Secondly, AREDS2 was performed and lutein/zeaxanthin was added to the first formulation to demonstrate the effects of them on AMD [73]. Both groups showed impairment on AMD. However the consumption of $\beta$-carotene can be a risk factor in the development of lung cancer for smokers, ex-smokers and subjects exposed to asbestos [74]. For all this, it was concluded that lutein/zeaxanthin supplements were better choices for treatment of AMD compared to $\beta$-carotene [79,80]. In a study among hospital patients in South India who were suffering from AMD, as the consumption of lutein and zeaxanthin increased, the risk of AMD decreased. In addition, the risk of AMD might reduce by taking cigarettes and alcohol [81].

\subsection{Role of Lutein and Zeaxanthin in Uveitis}

Lutein might play a protective and regulative role in mice suffered from the lipopolysaccharides (LPS)-induced uveitis. $B A L B / C$ mice were treated with different concentrations of lutein in drinking water for five days. Then uveitis formed in the eyes of these mice by applying LPS into the foot-pad. After the treatment, eyes were collected and several indicators were measured including, nitric oxide (NO), MDA, oxygen radical antioxidant capacity (ORAC), GSH, vitamin C levels, the enzymatic activities of SOD and glutathione peroxidase (GPx) in the eye homogenates. NO, MDA and ORAC levels decreased while the activities of SOD and GPx increased significantly in the eyes of the mice treated with lutein. Moreover, oral lutein intake improved the vitamin C and GSH levels in the eyes of the mice [82]. Sasaki $\mathrm{M}$ et al. conducted a study to evaluate the neuroprotective effects of lutein against retinal inflammation in mice with EUI. LPS was injected into the mice intraperitoneally (ip) to induce EUI, then lutein was administered by subcutaneous (sc) injection. It is suggested that lutein was a protective supplement on photoreceptor cells by decreasing production of reactive oxygen species which were causing visual damages, reduced rhodopsin (RHO) levels and induced GFAP expressions [83]. 


\subsection{Role of Lutein and Zeaxanthin in Glaucoma}

Igras et al. conducted a study to evaluate the relationship between macular pigments, oxidative damage and glaucoma. MPOD was higher in the control group $(n=54)$ than patients with open angle glaucoma $(n=40)$. Also glare was a problem for more than half of patients with glaucoma and not for the control group [84]. A strong relationship was found between eating habits and the development and progression of eye diseases. A healthy diet containing fruits and vegetables, which were rich in vitamin A, vitamin C, vitamin E, carotenoids such as lutein and zeaxanthin might lead to an increase of the risk of glaucoma among older African-American women [85]. The levels of MPOD were higher in subjects with open-angle glaucoma who had glaucomatous eyes without foveal involvement than with foveal involvement [86].

\subsection{Role of Lutein and Zeaxanthin in Diabetic Retinopathy}

Serum concentrations of lutein and zeaxanthin and the visual effects of them on subjects with/without non-proliferative diabetic retinopathy were investigated. Three groups of subjects; patients with non-proliferative diabetic retinopathy treated with lutein and zeaxanthin for three months, patients with non-proliferative diabetic retinopathy without any supplementation (diabetic retinopathy control group) and healthy subjects (control group) were investigated. Serum lutein and zeaxanthin concentrations in the control group were significantly higher than the treated group. Furthermore, foveal thickness decreased while contrast sensitivity increased significantly after the treatment compared with pre-medication [87]. There was a relationship between serum and dietary levels of lutein/zeaxanthin and MPOD [88]. Macular pigment and hemoglobin A1c (HbA1c) levels were compared in patients with type 2 diabetes (with/without retinopathy) and nondiabetics. MPOD values were higher while $\mathrm{HbA} 1 \mathrm{c}$ levels were lower in nondiabetic subjects than diabetics. It can be considered that impaired glycemic control could cause defects in retinal absorption and dispersion of lutein and zeaxanthin [89].

\subsection{Role of Lutein and Zeaxanthin in Retinal Ischemia}

Retinal ischemia/reperfusion (I/R) causes irreversible structural and functional damages in retina resulting in neurodegeneration [90]. Lutein is used to protect retinal neurons against oxidative stress resulting in ischemia/reperfusion due to its potent antioxidant profile. The effects of several antioxidants such as $\alpha$-tocopherol, lutein, Trigonella foenum-graecum Linn. ) and Teucrium multicaule Montbret \& Aucher ex Benth. were investigated in rats with ischemia-reperfusion injury. Lutein treatment caused a significant decrease in the levels of MDA as an indicator of lipid peroxidation and a considerable increase in GSH and also inhibition in the I/R-induced activation of caspase-3 [91]. Anti-inflammatory potential of lutein was investigated in in-vivo and in-vitro conditions. The levels of NF-KB, IL- $1 \beta$, and COX-2 dramatically reduced, but not TNF- $\alpha$ and cell viability increased in luteintreated Müller cells. Furthermore, lutein administration restored electroretinogram values caused by I/R injury controversially and also gliosis which was a formation of a glial scar was decreased [92]. Ip administration of lutein to Sprague-Dawley rats with retinal detachment minimized GFAP levels and remained the expression of RHO. Furthermore the treatment resulted in a reduction of caspase-3, cleaved caspase- 8 expression and no difference in caspase-9 [93]. There had been significant increases in the levels of nitrotyrosine (NT) and poly-ADP-ribose (PAR) as a marker of apoptosis in mice with $\mathrm{I} / \mathrm{R}$ injury treated with lutein [94].

\subsection{Role of Lutein and Zeaxanthin in CHM and Other Eye Disease}

The levels of lutein and zeaxanthin in patients with RP, CHM, Stargardt macular dystrophy and healthy subjects were compared by using resonance Raman spectroscopy. There was no significant difference between the patients with RP, CHM and the subjects who had no macular pathologic condition. Despite the fact that patients with Stargardt macular dystrophy showed lower levels of 
macular carotenoids than the control groups [95]. The levels of macular pigments, the defects of rodcone function and structure of central retina were determined. Foveal vision and macular pigment relation was evaluated after 6 months of oral lutein treatment. Serum macular pigment levels increased as a result of lutein supplementation while foveal sensitivity was stable in patients with CHM [96].

\section{Conclusions}

Carotenoids, which absorb a wavelength range of 350-550 $\mathrm{nm}$ are nonpolar organic pigments divided into two major groups; carotenes and xanthophylls [4]. The group of xanthophylls includes lutein, zeaxanthin, neoxanthin, violaxanthin etc [5]. Lutein and zeaxanthin are accumulated in lipophilic tissues such as adipose and liver tissue [44,45]. These are the only carotenoids called macular xanthophylls deposited in the human lens and found abundantly in the macula lutea which is the responsible area of vision [97,98]. Macula of retina is yellow due to rich lutein and zeaxanthin content. Lutein and zeaxanthin absorb near-ultraviolet and blue light, so macula is protected against phototoxic damage. Additionally, lutein and zeaxanthin have free-radical scavenging, antiinflammatory and antitumor potential [99]. Based on this, lutein and zeaxanthin may be used to protect subjects against inflammatory diseases of the eye including, AMD, uveitis, RP, scleritis and also cataract, glaucoma, retinal ischemia, CHM, etc. The mechanisms of protective effects of lutein against retinal damage have not been revealed yet exactly. However, there are several aspects about the mechanism. One is that lutein and zeaxanthin protect retina against oxidative stress from the damage of blue-light by inhibiting lipid peroxidation and c-fos gene expression [16,17]. The other is about antioxidant properties of lutein and zeaxanthin that are highly potent quenchers of singlet oxygens and other free radicals $[18,19,20]$. With all this, further studies are necessary to quietly determine exact mechanisms of protective effects of these macular pigments.

\section{Acknowledgments}

Funding and sponsorship: No external funding was associated with the production of this article. Declaration of interest: The authors have no relevant interests to declare.

\section{ORCID}

Sezen Y1lmaz Sarialtın :0000-0002-8387-4146

Tulay Coban: $\underline{0000-0002-9696-6613}$

\section{References}

[1] W. Stuetz, W. Schlörmann and M. Glei (2017). B-vitamins, carotenoids and $\alpha$-/ $\gamma$-tocopherol in raw and roasted nuts, Food Chem. 221, 222-227.

[2] N. Mohammadzadeh Honarvar, A. Saedisomeolia, M. Abdolahi, A. Shayeganrad, G. Taheri Sangsari, B. Hassanzadeh Rad and G. Muench (2017). Molecular anti-inflammatory mechanisms of retinoids and carotenoids in Alzheimer's disease: A review of current evidence, J. Mol. Neurosci. 61, 289-304.

[3] D. Kelly, R.F. Coen, K.O. Akuffo, S. Beatty, J. Dennison, R. Moran, J. Stack, A.N. Howard, R. Mulcahy and J.M. Nolan (2015). Cognitive function and its relationship with macular pigment optical density and serum concentrations of its constituent carotenoids, J. Alzheimers. Dis. 48, 261-277.

[4] G. Britton, S. Liaaen-Jensen and H. Pfander (2008). Carotenoids, Vol. 4: Natural Functions. Basel, Birkhäuser verlag.

[5] S. Zaripheh and J.W.Jr. Erdman (2002). Factors that influence the bioavailablity of xanthophylls, $J$. Nutr. 132, 531S-534S.

[6] H. Hashimoto, C. Uragami and R.J. Cogdell (2016). Carotenoids and photosynthesis, Subcell. Biochem. 79,111-139. 
[7] R. Vishwanathan, W. Schalch and E.J. Johnson (2016). Macular pigment carotenoids in the retina and occipital cortex are related in humans, Nutr. Neurosci. 19, 95-101.

[8] I.E. Apanasenko, O.Y. Selyutina, N.E. Polyakov, L.P. Suntsova, E.S. Meteleva, A.V. Dushkin, P. Vachali and P.S. Bernstein (2015). Solubilization and stabilization of macular carotenoids by water soluble oligosaccharides and polysaccharides, Arch. Biochem. Biophys. 572, 58-65.

[9] B.R. Hammond (2015). Foveal Morphology and the Macular Carotenoids, Invest Ophthalmol Vis Sci. 56, 13,7866 .

[10] U.S. National Library of Medicine National Center for Biotechnology Information 2017. Available at:http://pubchem.ncbi.nlm.nih.gov/compound/5280899\#section=Top/, https://pubchem.ncbi.nlm.nih.gov/compound/5281243\#section=Top. Accessed on January 14, 2017.

[11] O. Sommerburgb, J.E. Keunen, A.C. Bird and F.J. van Kuijk (1998). Fruits and vegetables that are sources for lutein and zeaxanthin: the macular pigment in human eyes, Br J Ophthalmol. 82, 907-910.

[12] U.S. Department of Agriculture, Agricultural Research Service. USDA National Nutrient Database for Standard Reference, Release 22. 2009 Nutrient Data Laboratory Home Page, http://ndb.nal.usda.gov/ndb/search. Accessed on January 14, 2017.

[13] A. Vogelsang, R.A. van Lingen, J. Slootstra, B.D. Dikkeschei, B.J. Kollen, A. Schaafsma and D. van Zoeren-Grobben (2009). Antioxidant role of plasma carotenoids in bronchopulmonary dysplasia in preterm infants, Int. J. Vitam. Nutr. Res. 79, (5-6),288-296.

[14] D.B. Haytowitz, L.E. Lemar, P.R. Pehrsson, J. Exler, K.K. Patterson, R.G. Thomas, M.S. Nickle, J.R. Williams, B.A. Showell, M. Khan, M. Duvall and J.M. Holden (2011). USDA National Nutrient Database for Standard Reference, Release 24. Beltsville: U.S. Department of Agriculture, Agricultural Research Service.

[15] U.S. Department of Agriculture, Agricultural Research Service. 2015 USDA National Nutrient Database for Standard Reference, Release 28. Nutrient Data Laboratory Home Page, http://ndb.nal.usda.gov/ndb/search. Accessed on January 14, 2017.

[16] X. Xu and X. Lin (2010). Molecular mechanism of the protective effect of lutein against retinal damage induced by blue-light in rats, Wei. Sheng. Yan. Jiu. 39, 689-692.

[17] M.X. Wang, J.H. Jiao, Z.Y. Li, R.R. Liu, Q. Shi and L. Ma (2013). Lutein supplementation reduces plasma lipid peroxidation and C-reactive protein in healthy nonsmokers, Atherosclerosis 227, 380-385.

[18] S.Y. Du, Y.L. Zhang, R.X. Bai, Z.L. Ai, B.S. Xie and H.Y. Yang (2015). Lutein prevents alcoholinduced liver disease in rats by modulating oxidative stress and inflammation, Int. J. Clin. Exp. Med. 8, 8785-8793.

[19] A.Q. Ashton (2013). Xanthophylls: Advances in Research and Application. Atlanta, Scholarly Editions.

[20] G. Riccioni, N. D'Orazio, C. Salvatore, S. Franceschelli, M. Pesce and L. Speranza (2012). Carotenoids and vitamins $\mathrm{C}$ and $\mathrm{E}$ in the prevention of cardiovascular disease, Int. J. Vitam. Nutr. Res. 82, 15-26.

[21] J. Nataraj, T. Manivasagam, A.J. Thenmozhi and M.M. Essa (2016). Lutein protects dopaminergic neurons against MPTP-induced apoptotic death and motor dysfunction by ameliorating mitochondrial disruption and oxidative stress, Nutr. Neurosci. 19, 237-246.

[22] M.W. Sahli, J.A. Mares, K.J. Meyers, R. Klein, W.E. Brady, B.E. Klein, H.M. Ochs-Balcom, R.P. Donahue and A.E. Millen (2016). Dietary intake of lutein and diabetic retinopathy in the Atherosclerosis risk in communities study (ARIC), Ophthalmic. Epidemiol. 23, 99-108.

[23] J.E. Roberts and J. Dennison (2015). The Photobiology of lutein and xeaxanthin in the eye, J. Ophthalmol. 2015, 687173.

[24] A. Sulich, J. Hamułka and D. Nogal (2015). Dietary sources of lutein in adults suffering eye disease (AMD/cataracts), Rocz. Panstw. Zakl. Hig. 66, 55-60.

[25] R. Hayashi, S. Hayashi, K. Arai, M. Sakai, H. Okamoto and M. Chikuda (2014). The genderdifferentiated antioxidant effects of a lutein-containing supplement in the aqueous humor of patients with senile cataracts, Exp. Eye Res. 129, 5-12.

[26] R.K. Murthy, K. Ravi, S. Balaiya, V.S. Brar and K.V. Chalam (2014). Lutein protects retinal pigment epithelium from cytotoxic oxidative stress, Cutan. Ocul. Toxicol. 33, 132-137.

[27] S. Fujimura, K. Ueda, Y. Nomura and Y. Yanagi (2016). Preliminary analysis of the relationship between serum lutein and zeaxanthin levels and macular pigment optical density, Clin. Ophthalmol.10, 2149-2155.

[28] L. Ma, R. Liu, J.H. Du, T. Liu, S.S. Wu and X.H. Liu (2016). Lutein, zeaxanthin and mesozeaxanthin supplementation associated with macular pigment optical density, Nutrients 8, (7).426.

[29] J. Mares (2016). Lutein and zeaxanthin isomers in eye health and disease, Annu. Rev. Nutr. 36, 571602. 
[30] A. Manayi, M. Abdollahi, T. Raman, S.F. Nabavi, S. Habtemariam, M. Daglia and S.M. Nabavi (2016). Lutein and cataract: from bench to bedside, Crit. Rev. Biotechnol. 36, 829-839.

[31] U.E. Wolf-Schnurrbusch, M.S. Zinkernagel, M.R. Munk, A. Ebneter and S Wolf (2015). Oral lutein supplementation enhances macular pigment density and contrast sensitivity but not in combination with polyunsaturated fatty acids, Invest. Ophthalmol. Vis. Sci. 56, 8069-8074.

[32] X.H. Liu, R.B. Yu, R. Liu, Z.X. Hao, C.C. Han, Z.H. Zhu and L. Ma (2014). Association between lutein and zeaxanthin status and the risk of cataract: a meta-analysis, Nutrients 6, 452-465.

[33] L. Ma, Z.X. Hao, R.R. Liu, R.B. Yu, Q. Shi and J.P. Pan (2014). A dose-response meta-analysis of dietary lutein and zeaxanthin intake in relation to risk of age-related cataract., Graefes. Arch. Clin. Exp. Ophthalmol. 252, 63-70.

[34] J.M. Seddon, U.A. Ajani, R.D. Sperduto, R. Hiller, N. Blair, T.C. Burton, M.D. Farber, E.S. Gragoudas, J. Haller and D.T. Miller (1994). Dietary carotenoids, vitamins A, C, and E, and advanced age related macular degeneration. Eye Disease Case-Control Study Group, JAMA. 272, 1413-1420.

[35] L. Ma, S.F. Yan, Y.M. Huang, X.R. Lu, F. Qian, H.L. Pang, X.R. Xu, Z.Y. Zou, P.C. Dong, X. Xiao, X. Wang, T.T. Sun, H.L. Dou and X.M. Lin (2012). Effect of lutein and zeaxanthin on macular pigment and visual function in patients with early age-related macular degeneration, Ophthalmology 119, 22902297.

[36] E. Loane, G.J. McKay, J.M. Nolan and S. Beatty (2010). Apolipoprotein E genotype is associated with macular pigment optical density, Invest. Ophthalmol. Vis. Sci. 51, 2636-2643.

[37] L.M. Renzi, B.R. Jr. Hammond, M. Dengler and R. Roberts (2012). The relation between serum lipids and lutein and zexanthin in the serum and retina: results from cross-sectional, case-control and case study designs, Lipids Health Dis. 11, 33-42.

[38] V. Juturu, J.P. Bowman and J. Deshpande (2016). Overall skin tone and skin-lightening-improving effects with oral supplementation of lutein and zeaxanthin isomers: a double-blind, placebo-controlled clinical trial, Clin. Cosmet. Investig. Dermatol. 9, 325-332.

[39] C. Xue, R. Rosen, A. Jordan and D.N. Hu (2015). Management of ocular diseases using lutein and zeaxanthin: What have we learned from experimental animal studies?, J. Ophthalmol. 2015, 523027.

[40] R. Vishwanathan, M. Neuringer, D.M. Snodderly, W. Schalch and E.J. Johnson (2013). Macular lutein and zeaxanthin are related to brain lutein and zeaxanthin in primates, Nutr. Neurosci. 16, 21-29.

[41] Q. Bian, S. Gao, J. Zhou, J. Qin, A. Taylor, E.J. Johnson, G. Tang, J.R. Sparrow, D. Gierhart and F. Shang (2012). Lutein and zeaxanthin supplementation reduces photooxidative damage and modulates the expression of inflammation-related genes in retinal pigment epithelial cells, Free Radic. Biol. Med. 53, 1298-1307.

[42] D. Sousa-Martins, M. Maia, M. Moraes, A.A. Lima-Filho, E.B. Rodrigues, J. Chen, M.E. Farah, L.B. Santos and R. Jr. Belfort (2012). Use of lutein and zeaxanthin alone or combined with Brilliant Blue to identify intraocular structures intraoperatively, Retina 32, 1328-1336.

[43] K. Izumi-Nagai, N. Nagai, K. Ohgami, S. Satofuka, Y. Ozawa, K. Tsubota, K. Umezawa, S. Ohno, Y. Oike and S. Ishida (2007). Macular pigment lutein is antiinflammatory in preventing choroidal neovascularization, Arterioscler. Thromb. Vasc. Biol. 27, 2555-2562.

[44] L.A. Kaplan, J.M. Lau and E.A. Stein (1990). Carotenoid composition, concentrations, and relationships in various human organs, Clin. Physiol. Biochem. 8, 1-10.

[45] H.H. Schmitz, C.L. Poor, R.B. Wellman and, J.W.Jr. Erdman (1991). Concentrations of selected carotenoids and vitamin A in human liver, kidney and lung tissue, J. Nutr. 121, 1613-1621.

[46] M. Korkaric, M. Xiao, R. Behra and R.I. Eggen (2015). Acclimation of chlamydomonas reinhardtii to ultraviolet radiation and its impact on chemical toxicity, Aquat. Toxicol. 167, 209-219.

[47] A. Freitas, M. Moldão-Martins, H.S. Costa, T.G. Albuquerque, A. Valente and A. Sanches-Silva. Effect of UV-C radiation on bioactive compounds of pineapple (Ananas comosus L. Merr.) by-products (2015), J. Sci. Food. Agric. 95, 44-52.

[48] S. Pongcharoen, P. Warnnissorn, O. Leṛtkajornsin, N. Limpeanchob and M. Sutheerawattananonda (2013). Protective effect of silk lutein on ultraviolet B-irradiated human keratinocytes, Biol. Res. 46, 3945.

[49] M. Sasaki, Y. Ozawa, T. Kurihara, K. Noda, Y. Imamura, S. Kobayashi, S. Ishida and K. Tsubota (2009). Neuroprotective effect of an antioxidant, lutein, during retinal inflammation, Invest. Ophthalmol. Vis. Sci. 50, 1433-1439. 
[50] J. Nataraj, T. Manivasagam, A.J. Thenmozhi and M.M. Essa (2016). Lutein protects dopaminergic neurons against MPTP-induced apoptotic death and motor dysfunction by ameliorating mitochondrial disruption and oxidative stress, Nutr. Neurosci. 19, 237-246.

[51] Y.X. Sun, T. Liu, X.L. Dai, Q.S. Zheng, B.D. Hui and Z.F. Jiang (2014). Treatment with lutein provides neuroprotection in mice subjected to transient cerebral ischemia, J. Asian. Nat. Prod. Res. 16, 10841093.

[52] M.M. Raf, S. Kanakasabai, S.V. Gokarn, E.G. Krueger and J.J. Bright (2015). Dietary lutein modulates growth and survival genes in prostate cancer cells, J. Med. Food. 18, 173-181.

[53] S.O. Antwi, S.E. Steck, H. Zhang, L. Stumm, J. Zhang, T.G. Hurley and J.R. Hebert (2015). Plasma carotenoids and tocopherols in relation to prostate-specific antigen (PSA) levels among men with biochemical recurrence of prostate cancer, Cancer Epidemiol. 39, 752-762.

[54] Y.X. Pei, Z.C. Heng, G.C. Duan and M.C. Wang (2007). The mechanisms and effects of lutein on inducing the cell differentiation of human esophagus cancer, Sich. Da Xue Xue Bao Yi Xue Ban. 38, 629-632.

[55] N. Philips, T. Keller, C. Hendrix, S. Hamilton, R. Arena, M. Tuason and S. Gonzalez (2007). Regulation of the extracellular matrix remodeling by lutein in dermal fibroblasts, melanoma cells, and ultraviolet radiation exposed fibroblasts, Arch. Dermatol. Res. 299, 373-379.

[56] L.K. Moshetova, IV. Vorob'ev, I.B. Alekseev and L.G. Mikhaleva (2015). Results of the use of antioxidant and angioprotective agents in type 2 diabetes patients with diabetic retinopathy and agerelated macular degeneration, Vestn. Oftalmol. 131, 34-44.

[57] X. Qiu, D.H. Gao, X. Xiang, Y.F. Xiong, T.S. Zhu, L.G. Liu, X.F. Sun and L.P. Hao (2015). Ameliorative effects of lutein on non-alcoholic fatty liver disease in rats, World J. Gastroenterol. 21, 8061-8072.

[58] E. Arnal, M. Miranda, J. Barcia, F. Bosch-Morell and F.J. Romero (2010). Lutein and docosahexaenoic acid prevent cortex lipid peroxidation in streptozotocin-induced diabetic rat cerebral cortex, Neuroscience 166, 271-278.

[59] J. Oh, J.H. Kim, J.G. Park, Y.S. Yi, K.W. Park, H.S. Rho, M.S. Lee, J.W. Yoo, S.H. Kang, Y.D. Hong, S.S. Shin and J.Y. Cho (2013). Radical scavenging activity-based and AP-1-targeted anti-inflammatory effects of lutein in macrophage-like and skin keratinocytic cells, Mediators Inflamm. 2013, 787042. doi: $10.1155 / 2013 / 787042$.

[60] G. Crichton, M. Elias, A. Alkerwi and J. Buckley (2015). Intake of lutein-rich vegetables is associated with higher levels of physical activity, Nutrients 7, 8058-8071.

[61] E.T. Leermakers, J.C. Kiefte-de Jong, A. Hofman, V.W. Jaddoe and O.H. Franco (2015). Lutein intake at the age of 1 year and cardiometabolic health at the age of 6 years: the Generation R Study, Br J Nutr. 114, 970-8.

[62] D.E. Bonds, M. Harrington, B.B. Worrall, A.G. Bertoni, C.B. Eaton, J. Hsia, J. Robinson, T.E. Clemons, L.J. Fine and E.Y. Chew (2014). Effect of long-chain $\omega$-3 fatty acids and lutein+zeaxanthin supplements on cardiovascular outcomes: Results of the age-related eye disease study 2 (AREDS2) randomized clinical trial, JAMA Intern. Med. 174, 763-771.

[63] R.L. Roberts, J. Green and B. Lewis (2009). Lutein and zeaxanthin in eye and skin health, Clin Dermatol. 27, 195-201.

[64] S. Grether-Beck, A. Marini, T. Jaenicke, W. Stahl and J. Krutmann (2016). Molecular evidence that oral supplementation with lycopene or lutein protects human skin against ultraviolet radiation: Results from a double-blinded, placebo-controlled, cross-over study, Br. J. Dermatol. 17, 1231-1240.

[65] V. Juturu, J.P. Bowman and J. Deshpande (2016). Overall skin tone and skin-lightening-improving effects with oral supplementation of lutein and zeaxanthin isomers: a double-blind, placebo-controlled clinical trial, Clin. Cosmet. Investig. Dermatol. 9, 325-332.

[66] G. Goutham, R. Manikandan, M. Beulaja, R. Thiagarajan, C. Arulvasu, M. Arumugam, W.N. Setzer, M. Daglia, S.F. Nabavi and S.M. Nabavi (2016). A focus on resveratrol and ocular problems, especially cataract: From chemistry to medical uses and clinical relevance, Biomed. Pharmacother. 86, 232-241.

[67] N. Pescosolido, A. Barbato, R. Giannotti, C. Komaiha and F. Lenarduzzi (2016). Age-related changes in the kinetics of human lenses: prevention of the cataract, Int. J. Ophthalmol. 9, 1506-1517.

[68] D. Škiljić, S. Nilsson, A. Petersen, J.O. Karlsson, A. Behndig, L. Kalaboukhova and M. Zetterberg (2016). Oestradiol levels and superoxide dismutase activity in age-related cataract: a case-control study, BMC Ophthalmol. 16, 210-214. 
[69] J. Karppi, J.A. Laukkanen and S. Kurl (2012). Plasma lutein and zeaxanthin and the risk of age-related nuclear cataract among the elderly Finnish population, Br. J. Nutr. 108, 148-154.

[70] C. Delcourt, I. Carrière, M. Delage, P. Barberger-Gateau and W. Schalch (2006). Plasma lutein and zeaxanthin and other carotenoids as modifiable risk factors for age-related maculopathy and cataract, Invest. Ophthalmol. Vis. Sci. 47(6), 2329-2335.

[71] R. Hayashi, S. Hayashi, K. Arai, M. Sakai, H. Okamoto and M. Chikuda (2014). The genderdifferentiated antioxidant effects of a lutein-containing supplement in the aqueous humor of patients with senile cataracts, Exp. Eye Res. 129, 5-12.

[72] L.M. Vianna, M.J. Cohen, C. Muccioli, A. Lima, D. Sousa-Martins, M. Maia and Jr. R. Belfort (2014). Efficacy of a lutein-based dye (PhacodyneTM) for visualizing anterior capsulorhexis during cataract surgery by phacoemulsification, Arq. Bras. Oftalmol. 77, 173-177.

[73] E.Y. Chew, J.P. SanGiovanni, F.L. Ferris, W.T. Wong, E. Agron, T.E. Clemons, R. Sperduto, R. Danis, S.R. Chandra, B.A. Blodi, A. Domalpally, M.J. Elman, A.N. Antoszyk, A.J. Ruby, D. Orth, S.B. Bressler, G.E. Fish, G.B. Hubbard, M.L. Klein, T.R. Friberg, P.J. Rosenfeld, C.A. Toth and P. Bernstein (2013). Lutein/Zeaxanthin for the Treatment of Age-Related Cataract AREDS2 Randomized Trial Report No. 4, JAMA Ophthalmol. 131, 843-850.

[74] R. Liu, T. Wang, B. Zhang, L. Qin, C. Wu, Q. Li and L. Ma (2014). Lutein and zeaxanthin supplementation and association with visual function in age-related macular degeneration: A metaanalysis, Invest. Ophthalmol. Vis. Sci. 56, 252-258.

[75] X. Wang, C. Jiang, Y. Zhang, Y. Gong, X. Chen and M. Zhang (2014). Role of lutein supplementation in the management of age-related macular degeneration: meta-analysis of randomized controlled trials, Ophthalmic Res. 52, 198-205.

[76] Y.M. Huang, H.L. Dou, F.F. Huang, X.R. Xu, Z.Y. Zou, X.R. Lu and X.M. Lin (2015). Changes following supplementation with lutein and zeaxanthin in retinal function in eyes with early agerelatedmacular degeneration: a randomised, double-blind, placebo controlled trial, Br. J. Ophthalmol. 99, 371-375.

[77] S.M. van der Made, E.R. Kelly, T.T. Berendschot, A. Kijlstra, D. Lütjohann and J. Plat (2014). Consuming a buttermilk drink containing lutein-enriched egg yolk daily for 1 year increased plasma lutein but did not affect serum lipid or lipoprotein concentrations in adults with early signs of age-related macular degeneration, J. Nutr. 144, 1370-1377.

[78] F.F. Huang and X.M. Lin (2014). Comparison of daily intake of lutein+zeaxanthin, serum concentration of lutein/zeaxanthin and lipids profile between age-related macular degeneration patients and controls, Beij. Da Xue Xue Bao. 46, 237-241.

[79] E.Y. Chew, T.E. Clemons, J.P. Sangiovanni, R.P. Danis, F.L. Ferris, M.J. Elman, A.N. Antoszyk, A.J. Ruby, D. Orth, S.B. Bressler, G.E. Fish, G.B. Hubbard, M.L. Klein, S.R. Chandra, B.A. Blodi, A. Domalpally, T. Friberg, W.T. Wong, P.J. Rosenfeld, E. Agrón, C.A. Toth, P.S. Bernstein and R.D. Sperduto (2014). Secondary analyses of the effects of lutein/zeaxanthin on age-related macular degeneration progression: AREDS2 report No. 3, JAMA Ophthalmol. 132, 142-149.

[80] J.A. Doherty, L.C. Sakoda, M.M. Loomis, M.J. Barnett, L. Julianto, M.D. Thornquist, M.L. Neuhouser, N.S. Weiss, G.E. Goodman and C. Chen (2013). DNA repair genotype and lung cancer risk in the betacarotene and retinol efficacy trial, Int. J. Mol. Epidemiol. Genet. 4, 11-34.

[81] B. Nidhi, B.S. Mamatha, C.A. Padmaprabhu, P. Pallavi and B. Vallikannan (2013). Dietary and lifestyle risk factors associated with age-related macular degeneration: a hospital based study, Indian J. Ophthalmol. 61, 722-77.

[82] R.R. He, B. Tsoi, F. Lan, N. Yao, X.S. Yao and H. Kurihara (2011). Antioxidant properties of lutein contribute to the protection against lipopolysaccharide-induced uveitis in mice, Chin. Med. 6, 38-45.

[83] M. Sasaki, Y. Ozawa, T. Kurihara, K. Noda, Y. Imamura, S. Kobayashi, S. Ishida and K. Tsubota (2009). Neuroprotective effect of an antioxidant, lutein, during retinal inflammation, Invest. Ophthalmol. Vis. Sci. 50, 1433-149.

[84] E. Igras, J. Loughman, M. Ratzlaff, R. O'Caoimh and C. O'Brien (2013).Evidence of lower macular pigment optical density in chronic open angle glaucoma, Br. J Ophthalmol. 77, 994-998.

[85] J.A. Giaconi, F. Yu, K.L. Stone, K.L. Pedula, K.E. Ensrud, J.A. Cauley, M.C. Hochberg and A.L. Coleman (2012). Study of osteoporotic fractures research group. The association of consumption of fruits/vegetables with decreased risk of glaucoma among older African-American women in the study of osteoporotic fractures, Am. J. Ophthalmol. 154, 635-644. 
[86] W.F. Siah, J. Loughman and C. O'Brien (2015). Lower macular pigment optical density in FovealInvolved Glaucoma, Ophthalmology 122, 2029-2037.

[87] B.J. Hu, Y.N. Hu, S. Lin, W.J. Ma and X.R. Li (2011). Application of lutein and zeaxanthin in nonproliferative diabetic retinopathy, Int. J. Ophthalmol. 4, 303-306.

[88] S. Beatty, J. Nolan, H. Kavanagh and O.O'Donovan (2004). Macular pigment optical density and its relationship with serum and dietary levels of lutein and zeaxanthin, Arch. Biochem. Biophys. 430, 7076.

[89] V.C. Lima, R.B. Rosen, M. Maia, T.S. Prata, S. Dorairaj, M.E. Farah and J. Sallum (2010). Macular pigment optical density measured by dual-wavelength autofluorescence imaging in diabetic and nondiabetic patients: a comparative study, Invest. Ophthalmol. Vis. Sci. 51(11),5840-5845.

[90] A. Muthusamy, C.M. Lin, S. Shanmugam, H.M. Lindner, S.F. Abcouwer and D.A. Antonetti (2014). Ischemia-reperfusion injury induces occludin phosphorylation/ubiquitination and retinal vascular permeability in a VEGFR-2-dependent manner, J. Cereb. Blood Flow Metab. 34, 522-531.

[91] N. Dilsiz, A. Sahaboglu, M.Z. Yildiz and A. Reichenbach (2006). Protective effects of various antioxidants during ischemia-reperfusion in the rat retina, Graefe's. Arch. Clin. Exp. Ophthalmol. 244, 627-633.

[92] S.Y. Li, F.K. Fung, Z.J. Fu, D. Wong, H.H. Chan and A.C. Lo (2012). Anti-inflammatory effects of lutein in retinal ischemic/hypoxic injury: in vivo and in vitro studies, Invest. Ophthalmol. Vis. Sci. 53, 5976-5984.

[93] T.T Woo, S.Y. Li, W.W. Lai, D. Wong and A.C. Lo (2013). Neuroprotective effects of lutein in a rat model of retinal detachment, Graefe's. Arch. Clin. Exp. Ophthalmol. 251, 41-51.

[94] S.Y. Li, Z.J. Fu, H. Ma, W.C. Jang, K.F. So, D. Wong and A.C. Lo (2009). Effect of lutein on retinal neurons and oxidative stress in amodel of acute retinal ischemia/reperfusion, Invest. Ophthalmol. Vis. Sci. 50, 836-843.

[95] D.Y. Zhao, S.W. Wintch, I.V. Ermakov, W. Gellermann and P.S. Bernstein (2003). Resonance raman measurement of macular carotenoids in retinal, choroidal, and macular dystrophies, Arch. Ophthalmol. 121, 967-972.

[96] J.L. Duncan, T.S. Aleman, L.M. Gardner, E. De Castro, D.A. Marks, J.M. Emmons, M.L. Bieber, J.D. Steinberg, J. Bennett, E.M. Stone, I.M. MacDonald, A.V. Cideciyan, M.G. Maguire and S.G. Jacobson (2002). Macular pigment and lutein supplementation in choroideremia, Exp. Eye Res. 74, 371-381.

[97] K.J. Yeum, A. Taylor, G. Tang and R.M. Russell (1995). Measurement of carotenoids, retinoids, and tocopherols inhuman lenses, Invest. Ophthalmol. Vis. Sci. 36, 2756-2761.

[98] R.A. Bone, J.T. Landrum, L.M. Friedes, C.M. Gomez, M.D. Kilburn, E. Menendez, I. Vidal and W. Wang (1997). Distribution of lutein and zeaxanthin stereoisomers in the human retina, Exp. Eye Res. 64, 211-218.

[99] W. Wu, Y. Li, Y. Wu, Y. Zhang, Z. Wang and X. Liu (2015). Lutein suppresses inflammatory responses through $\mathrm{Nrf} 2$ activation and $\mathrm{NF \kappa B}$ inactivation in lipopolysaccharide-stimulated BV-2 microglia, Mol. Nutr. Food Res. 59, 1663-1673.

$$
\text { A } \underset{\substack{\text { publications } \\ \text { (C) } 2018 \text { ACG Publications }}}{\text { G }}
$$

